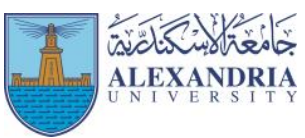

\title{
The Effect of Using Facebook on Spreading Health Education among Zagazig University Students
}

\author{
Gehan Yahia Mahmoud ${ }^{1}$ \\ ${ }^{1}$ Assistant Professor, Health Sciences Department, Faculty of Physical Education for Girls, Zagazig University, Egypt
}

\begin{abstract}
The main purpose of the present study is to identify: the health education level of students in Zagazig University - the effect of using Facebook on spreading the health education of the students- the differences in the health education level between students based on: gender-place of living ( rural vs urban )- major ( humanities vs scientific). The researcher used the descriptive approach because it was most suitable for the nature of the study. The sample (N=235) was randomly chosen from Zagazig University students. For data collection, the researcher used the health education questionnaire and the Facebook's effect questionnaire. This study found that : the sample had a high health education level ,Facebook affects the health education level of the students, there are differences between male and female students in some health education dimensions for the males whereas there are no differences between them in Facebook's effect. The study also found that, there are statistically significant differences between rural and urban students in some of the health education dimensions for the latter group whereas there are differences between them in Facebook's effect for the rural students. There are statistically significant differences between the science and the humanities majors in some dimensions of health and in Facebook's effect of for the humanities major students.
\end{abstract}

\section{Introduction}

Social networks, known as the new social media, are Sthe latest and most popular communication technology innovation. Their unique features which distinguish them from the other internet websites make them more popular. As a result, more surfers all over the world are attracted to these networks. Facebook, for example, helps make friendships and exchange information, personal photos and videos and comment on them with the possibility of instant messaging and chatting. It also facilitates making relationships in a short time Al Mansour(2012). This concurs with Karbiniski's Study (2010).

Social networks have become important institutions that play an important role in raising young people and acquiring them proper habits and behaviours. They are also important tools in social change. This concurs with Vansoon's study (2010). Educational and social institutions have given a lot of care to developing programs and activities for young people, aiming to help them pass leisure time in useful ways, instil important aspects in their personalities and try to develop balanced personalities.
Educators have become more aware of the importance of the social media sites and their role in polishing and developing personalities of the youth. Studies in 2010 showed that the Facebook Arab users were around 15 million, with 3.5 million Egyptians, $4.5 \%$ of the overall Egyptian population.

Henceforth, the importance of interacting with others in different events in groups formed within the social networks is highlighted. One area of interaction is health education. These sites have become the main and most popular tool for spreading different areas of health education through brining about the cognitive change, as mass media are very influential in the cognitive structure of people though long exposure to these media as reliable sources of information.

Khalil (2006) states that health education aims to (form right health attitudes by following the health instructions and increasing the health awareness, form positive healthy habits and practices to achieve disease prevention and a healthy community, and provide people with the basic health information, suitable to their educational level, to develop the mental awareness of the physical, psychological and social health and the individual responsibilities in that respect Khalil (2006). 
Social networks are the more important ways of communication. One can find information about their diseases, infection, ways of prevention and treatment through visiting specialized medical websites. Thus, the internet can provide patients with all the necessary information, which makes the medical sites a source of health education. About 82 million medical sites enrich the internet with huge amount of information and data about any disease man can have. As a result, patients can now play a positive role in the health care area through equipping themselves with information that they can discuss with their doctors(20).

\section{Research problem}

A survey by Bayet.com (2011) showed that most Arabs use the internet for chatting with friends or making new friends, compared to non-Arab users who use it for online shopping, e-learning or finding a job.

Further, involvement in the online social activities is the main use of the internet in the Arab region, with average daily time of three hours at least. The results showed that $67 \%$ of the participants use the internet to network socially (21). That finding concurs with Al Shehry (2013) , Nosseir (2013), Streck (2011), Khdr (2009).

Facebook is full of health related pages that deal with personal hygiene, nutrition, posture among other topics. "Sehaty ", "Sehaty \& Rashqaty", "Sayedty \& Teflek" are examples of such pages.

Due to Facebook's popularity among different age groups , especially young people, it has become important to utilize it in enhancing the health education as it can reformulate the health education concepts and present them in more attractive and exciting ways that cope up with the fast changes and advancements in the field, as stated by Al Deleemy \& Maeiyta (2014) \& Ahmed (2009).

The main purpose of the present study is to identify the effect of using Facebook on spreading the health education among students in Zagazig University and its effect on this age group.

\section{Research Objectives}

The main purpose of the present study is to identify:

1- The health education level of students in Zagazig University.

2- The effect of using Facebook on spreading the health education of Zagazig University students.
3- The gender differences in health education level.

4- The differences in the health education level between rural and urban students.

5- The differences in health education level between students in humanities and scientific majors.

\section{Research Questions}

1- What is the level of the health education of Zagazig University Students?

2- How does using Facebook affect spreading the health education among Zagazig University students?

3- Does health education level differ based on gender?

4- Does health education level differ between rural and urban students?

5- Does health education level differ based on major?

\section{Procedures}

\section{Methodology}

The descriptive approach was used and the 235-student sample was randomly chosen from Zagazig University in the academic year (2015-2016).

\section{Instruments \& Data Collection Tools}

A survey to measure the effect of Facebook was used. This survey was divided into three parts:

First: demographics of the sample.

Second: The health education through a group of dimensions: (personal hygiene- nutrition-environment health -healthy posture-disease prevention).

Third: The effect of using Facebook which includes:

a set of questions to measure the average use of Facebook by the students.

measuring the effect of Facebook on spreading the health education.

The pilot study included 100 students from inside and outside the main sample of the study to measure validity of the survey using the internal consistency method; first, the questionnaire was administered on the sample, then, correlation coefficients between the scores of the statements and the total score of the relevant dimension, and between the dimensions and the total score were calculated. The reliability coefficient was also calculated using the split halves for the answers of the pilot study 
sample for each dimension-Alpha Cronbach method) was also calculated.

The survey was administered on the main sample on January 15-16,2016.

\section{The Statistical Analysis}

SPSS was used in the statistical analysis.

\section{Findings, Analysis and Discussion}

Table (1)

Responses of the sample on the personal hygiene dimension $(\mathrm{N}=235)$

\begin{tabular}{|c|c|c|c|c|c|c|c|c|c|c|}
\hline $\mathrm{N}$ & Statements & & $\begin{array}{l}\text { Strongly } \\
\text { Agree }\end{array}$ & Agree & Neutral & Disagree & $\begin{array}{l}\text { Strongly } \\
\text { disagree }\end{array}$ & $\mathrm{Chi}^{2}$ & Mean & Order \\
\hline \multirow[t]{2}{*}{1} & \multirow{2}{*}{$\begin{array}{l}\text { Social media sites provide } \\
\text { information related to the general } \\
\text { health. }\end{array}$} & $\mathrm{F}$ & 40 & 148 & 40 & 7 & 0 & \multirow{2}{*}{193.13} & \multirow{2}{*}{3.94} & \multirow{2}{*}{ (1) } \\
\hline & & $\%$ & 16.7 & 61.9 & 16.7 & 2.9 & 0 & & & \\
\hline \multirow[t]{2}{*}{4} & \multirow{2}{*}{$\begin{array}{l}\text { Social media sites provide solutions } \\
\text { to health problems. }\end{array}$} & $\mathrm{F}$ & 59 & 121 & 48 & 5 & 2 & \multirow{2}{*}{200.21} & \multirow{2}{*}{3.93} & \multirow{2}{*}{ (2) } \\
\hline & & $\%$ & 24.7 & 50.6 & 20.1 & 2.1 & 0.9 & & & \\
\hline \multirow[t]{2}{*}{2} & \multirow{2}{*}{$\begin{array}{l}\text { Social media sites post information } \\
\text { about enough sleeping hours and rest } \\
\text { times suitable for everyone. }\end{array}$} & $\mathrm{F}$ & 31 & 91 & 64 & 31 & 18 & \multirow{2}{*}{76.12} & \multirow{2}{*}{3.36} & \multirow{2}{*}{ (3) } \\
\hline & & $\%$ & 13.0 & 38.1 & 26.8 & 13.0 & 7.5 & & & \\
\hline \multirow[t]{3}{*}{3} & \multirow{2}{*}{$\begin{array}{l}\text { Social media sites provide } \\
\text { information related to the general } \\
\text { health. }\end{array}$} & $\mathrm{F}$ & 53 & 131 & 36 & 12 & 3 & \multirow{2}{*}{220.72} & \multirow{2}{*}{3} & \multirow{2}{*}{ (4) } \\
\hline & & $\%$ & 22.2 & 54.8 & 15.1 & 5.0 & 1.3 & & & \\
\hline & $\begin{array}{l}\text { Mean of Total Score of the personal } \\
\text { hygiene }\end{array}$ & \multicolumn{9}{|c|}{15.21} \\
\hline
\end{tabular}

$\mathrm{Chi}^{2}$ values at $(0.05) .=9.488$

$\mathrm{F}=$ frequency

Table (1) shows a high level of the personal hygiene dimension. It also shows that $\mathrm{Chi}^{2}$ value ranged between 76.12 and 220.72, which are statistically significant at (0.05).This indicates that the statements of the personal hygiene dimension are the most important in health education of the students.

Table (1) also shows statistically significant differences for the response (Agree) in 4 statements which deal with information related to the general health, the solutions to get rid of diseases, keeping rest times, the enough sleeping hours suitable for each person as well as information that promotes general health. This indicates the importance of such information in spreading the health education of the personal hygiene.

Generally, knowing the general rules of personal hygiene is extremely important to everyone as following these rules carefully leads to improving and promoting the personal health through giving due care to things that can protect the individual from diseases and promote the health level, keep rest times, enough sleeping hours and practising the recreational activities to pass the leisure time in a positive way that strengthens the body and boasts the physical fitness and the body's efficiency Salma(2012), Ismail \& Abdel Fattah (2001). 
Table (2)

Responses of the sample on the nutrition dimension $(\mathrm{N}=235)$

\begin{tabular}{|c|c|c|c|c|c|c|c|c|c|c|}
\hline $\mathrm{N}$ & Statements & & $\begin{array}{l}\text { Strongly } \\
\text { Agree }\end{array}$ & Agree & Neutral & Disagree & $\begin{array}{l}\text { Strongly } \\
\text { disagree }\end{array}$ & $\mathrm{Chi}^{2}$ & Mean & Order \\
\hline \multirow[t]{2}{*}{4} & \multirow{2}{*}{$\begin{array}{l}\text { Social media sites post information } \\
\text { useful in identifying the harm caused } \\
\text { by of obesity and handling it. }\end{array}$} & $\mathrm{F}$ & 85 & 109 & 29 & 10 & 2 & \multirow{2}{*}{191.61} & \multirow{2}{*}{4.12} & \multirow{2}{*}{ (1) } \\
\hline & & $\%$ & 36.2 & 46.4 & 12.3 & 4.3 & 0.9 & & & \\
\hline \multirow[t]{2}{*}{7} & \multirow{2}{*}{$\begin{array}{l}\text { Social media sites post recipes for } \\
\text { diets to get rid of overweight. }\end{array}$} & $\mathrm{F}$ & 77 & 99 & 41 & 12 & 6 & \multirow{2}{*}{139.27} & \multirow{2}{*}{3.97} & \multirow{2}{*}{ (2) } \\
\hline & & $\%$ & 32.8 & 42.1 & 17.4 & 5.1 & 2.6 & & & \\
\hline \multirow[t]{2}{*}{5} & \multirow{2}{*}{$\begin{array}{l}\text { Social media sites post recipes for } \\
\text { healthy dishes that maintain the } \\
\text { general health. }\end{array}$} & $\mathrm{F}$ & 48 & 122 & 63 & 2 & 0 & \multirow{2}{*}{125.18} & \multirow{2}{*}{3.91} & \multirow{2}{*}{ (3) } \\
\hline & & $\%$ & 20.4 & 51.9 & 26.8 & 0.9 & 0 & & & \\
\hline \multirow[t]{2}{*}{1} & \multirow{2}{*}{$\begin{array}{l}\text { Social media sites help identify the } \\
\text { useful nutrients and the importance } \\
\text { of each one. }\end{array}$} & $\mathrm{F}$ & 55 & 89 & 85 & 6 & 0 & \multirow{2}{*}{74.90} & \multirow{2}{*}{3.82} & \multirow{2}{*}{ (4) } \\
\hline & & $\%$ & 23.4 & 37.9 & 36.2 & 2.6 & 0 & & & \\
\hline \multirow[t]{2}{*}{6} & \multirow{2}{*}{$\begin{array}{l}\text { Social media sites discusses topics } \\
\text { related to nutrition of the pregnant } \\
\text { and infants. }\end{array}$} & $\mathrm{F}$ & 54 & 100 & 55 & 26 & 0 & \multirow{2}{*}{47.84} & \multirow{2}{*}{3.77} & \multirow{2}{*}{ (5) } \\
\hline & & $\%$ & 23.0 & 42.6 & 23.4 & 11.1 & 0 & & & \\
\hline \multirow[t]{2}{*}{2} & \multirow{2}{*}{$\begin{array}{l}\text { Social media sites focus on healthy } \\
\text { habits and their role in leading a } \\
\text { healthy life. }\end{array}$} & $\mathrm{F}$ & 34 & 115 & 73 & 11 & 2 & \multirow{2}{*}{187.02} & \multirow{2}{*}{3.71} & \multirow{2}{*}{ (6) } \\
\hline & & $\%$ & 14.5 & 48.9 & 31.1 & 4.7 & 0.9 & & & \\
\hline \multirow[t]{2}{*}{3} & \multirow{2}{*}{$\begin{array}{l}\text { Social media sites help reach the } \\
\text { suitable nutrients for each health } \\
\text { condition. }\end{array}$} & $\mathrm{F}$ & 43 & 90 & 76 & 19 & 7 & \multirow{2}{*}{108.29} & \multirow{2}{*}{3.60} & \multirow{2}{*}{ (7) } \\
\hline & & $\%$ & 18.3 & 38.3 & 32.3 & 8.1 & 3.0 & & & \\
\hline & Mean of Total Score of nutrition & \multicolumn{9}{|c|}{96.24} \\
\hline
\end{tabular}

$\mathrm{Chi}^{2}$ values at $(0.05) .=9.488$

Table (2) shows a high level for the nutrition dimension. $\mathrm{Chi}^{2}$ values ranged between 47.84 and 191.61, which are significant values at $(0.05)$ This means that the students agreed that the statements in the nutrition dimension are the most important in the health education.

Table (2) also shows statistically significant differences for the response (Agree) in 7 statements; 1.2.3.4.5.6.7, which are related to the most popular topics among Facebook users - males \& females -when they search for nutrition-related information.
Nutrition plays an important role in establishing the general health rules. Abdel Wahaab (1995) stated that our bodies are what we eat; the body is like a building that needs some elements in certain amounts to form. If it does not get them, it suffers a deficit, just like the building. Any shortage in these food requirements can result in general weakness and sickness. If the diseases contracted are neglected, they cause serious health problems and diseases. 
Table (3)

Responses of the sample on the environmental health dimension ( $\mathrm{N}=235)$

\begin{tabular}{|c|c|c|c|c|c|c|c|c|c|c|}
\hline $\mathrm{N}$ & Statements & & $\begin{array}{l}\text { Strongly } \\
\text { Agree }\end{array}$ & Agree & Neutral & Disagree & $\begin{array}{l}\text { Strongly } \\
\text { disagree }\end{array}$ & $\mathrm{Chi}^{2}$ & Mean & Order \\
\hline \multirow[t]{2}{*}{4} & \multirow{2}{*}{$\begin{array}{l}\text { Social media sites post useful } \\
\text { information about how to conserve the } \\
\text { environment and the green areas and } \\
\text { their role in keeping the percentage of } \\
\text { oxygen in the air. }\end{array}$} & $\mathrm{F}$ & 58 & 81 & 62 & 26 & 8 & \multirow[b]{2}{*}{73.70} & \multirow[b]{2}{*}{3.65} & \multirow[b]{2}{*}{ (1) } \\
\hline & & $\%$ & 24.7 & 34.5 & 26.4 & 11.1 & 3.4 & & & \\
\hline \multirow[t]{2}{*}{2} & \multirow{2}{*}{$\begin{array}{l}\text { Social media sites care about } \\
\text { conserving a healthy environment. }\end{array}$} & $\mathrm{F}$ & 42 & 100 & 51 & 31 & 11 & \multirow{2}{*}{93.66} & \multirow{2}{*}{3.55} & \multirow{2}{*}{ (2) } \\
\hline & & $\%$ & 17.9 & 42.6 & 21.7 & 13.2 & 4.7 & & & \\
\hline \multirow[t]{2}{*}{3} & \multirow{2}{*}{$\begin{array}{l}\text { Social media sites have information } \\
\text { about high temperatures, the harm } \\
\text { they cause and dealing with it. }\end{array}$} & $\mathrm{F}$ & 38 & 108 & 47 & 28 & 14 & \multirow{2}{*}{111.74} & \multirow{2}{*}{3.54} & \multirow{2}{*}{ (3) } \\
\hline & & $\%$ & 16.2 & 46.0 & 20.0 & 11.9 & 6.0 & & & \\
\hline \multirow[t]{2}{*}{1} & \multirow{2}{*}{$\begin{array}{l}\text { The articles in the social media sites } \\
\text { enrich you with information about } \\
\text { conserving the water resources. }\end{array}$} & $\mathrm{F}$ & 48 & 50 & 83 & 31 & 23 & \multirow{2}{*}{45.48} & \multirow{2}{*}{3.29} & \multirow{2}{*}{ (4) } \\
\hline & & $\%$ & 20.4 & 21.3 & 35.3 & 13.2 & 9.8 & & & \\
\hline \multicolumn{2}{|r|}{$\begin{array}{c}\text { Mean of Total Score of the environmental } \\
\text { health }\end{array}$} & \multicolumn{9}{|c|}{14.05} \\
\hline
\end{tabular}

$\mathrm{Chi}^{2}$ values at $(0.05) .=9.488$

Table (3) shows the statistical significance of the statements included the environmental health dimension. $\mathrm{Chi}^{2}$ values ranged between 45.48 and 111.74. This means that the students agreed that the statements in the environmental health dimension are the most important in the health education.

Table (3) also shows statistically significant differences for the response (Agree) in 3 statements; 2,3,4, which reflects the attention given by Facebook to giving information about conserving the environment, the green areas and their role in keeping the percentage of oxygen in the air , ways of conserving the environmental health, high temperatures and the harm they can cause and dealing with it.
Environmental health is the most important factor in decreasing diseases especially infectious diseases such as cholera, Dysentery, Malaria, yellow fever, foodborne diseases especially dairy products Hagar \& Al Amin (1998).

Table (3) also shows statistically significant differences for the response (Neutral) in item 1 only. This indicates that most articles on Facebook enrich students with information about conserving the water resource. However, a few pages either personal or official are concerned with the environmental health. 
Table (4)

Responses of the sample on the posture health dimension $(\mathrm{N}=235)$

\begin{tabular}{|c|c|c|c|c|c|c|c|c|c|c|}
\hline $\mathrm{N}$ & Statements & & $\begin{array}{l}\text { Strongly } \\
\text { Agree }\end{array}$ & Agree & Neutral & Disagree & $\begin{array}{l}\text { Strongly } \\
\text { disagree }\end{array}$ & $\mathrm{Chi}^{2}$ & Mean & Order \\
\hline \multirow[t]{2}{*}{2} & \multirow{2}{*}{$\begin{array}{l}\text { The social media sites focus on the } \\
\text { importance of practising sports as a } \\
\text { way of having a good posture. }\end{array}$} & $\mathrm{F}$ & 45 & 118 & 64 & 6 & 2 & \multirow{2}{*}{192.34} & \multirow{2}{*}{3.84} & \multirow{2}{*}{ (1) } \\
\hline & & $\%$ & 19.1 & 50.2 & 27.2 & 2.6 & 0.9 & & & \\
\hline \multirow[t]{2}{*}{3} & \multirow{2}{*}{$\begin{array}{l}\text { The social media sites deal with the } \\
\text { incorrect postural habits, how to beat } \\
\text { them and how to avoid them. }\end{array}$} & $\mathrm{F}$ & 44 & 119 & 42 & 21 & 9 & \multirow{2}{*}{156.12} & \multirow{2}{*}{3.71} & \multirow{2}{*}{ (2) } \\
\hline & & $\%$ & 18.7 & 50.6 & 17.9 & 8.9 & 3.8 & & & \\
\hline \multirow[t]{2}{*}{1} & \multirow{2}{*}{$\begin{array}{l}\text { Some social media sites dedicate } \\
\text { some articles to the anatomy of the } \\
\text { body and the most important bones } \\
\text { and muscles. }\end{array}$} & $\mathrm{F}$ & 22 & 101 & 62 & 73 & 7 & \multirow[b]{2}{*}{114.51} & \multirow[b]{2}{*}{3.37} & \multirow[b]{2}{*}{ (3) } \\
\hline & & $\%$ & 9.4 & 43.0 & 26.4 & 18.3 & 3.0 & & & \\
\hline \multicolumn{2}{|r|}{ Mean of Total Score of the posture health } & \multicolumn{9}{|c|}{10.93} \\
\hline
\end{tabular}

$\mathrm{Chi}^{2}$ values at $(0.05) .=9.488$

Table (4) shows the statistical significance of the statements included the posture health dimension. $\mathrm{Chi}^{2}$ values ranged between 114.51 and 192.51, which are significant values at $(0.05)$. That indicates that the students agreed that the statements included in the good posture dimension are the most important in the health education.

Table (4) also shows statistically significant differences for the response (Agree) in all the 3 statements of the dimension indicating that Facebook pages are concerned with giving information about the importance of practising sports as a way of having a good posture, the incorrect posture- related habits and how to beat them and how to avoid them. Some social media sites dedicate some articles to the anatomy of the body and the most important bones and muscles. Although the response (Agree) is the most frequent, the total score of (Agree) and (Disagree) exceeds 142, which reflects poor content on the Facebook about the anatomy of the body and the most important bones in the human body.

Posture is so important that it acquires the individual good health, helps delay the emergence of the sickness and gives a presentable look and self-confidence Qassem (2005). 
Table (5)

Responses of the sample on the Prevention Dimension ( $\mathrm{N}=235)$

\begin{tabular}{|c|c|c|c|c|c|c|c|c|c|c|}
\hline $\mathrm{N}$ & Statements & & $\begin{array}{l}\text { Strongly } \\
\text { Agree }\end{array}$ & Agree & Neutral & Disagree & $\begin{array}{l}\text { Strongly } \\
\text { disagree }\end{array}$ & $\mathrm{Chi}^{2}$ & Mean & Order \\
\hline \multirow[t]{2}{*}{5} & \multirow{2}{*}{$\begin{array}{l}\text { The social media sites post } \\
\text { information on symptoms of different } \\
\text { diseases for early treatment and } \\
\text { avoiding complications }\end{array}$} & $\mathrm{F}$ & 55 & 107 & 58 & 13 & 2 & \multirow[b]{2}{*}{148,21} & \multirow[b]{2}{*}{3.85} & \multirow[b]{2}{*}{ (1) } \\
\hline & & $\%$ & 23.4 & 45.5 & 24.7 & 5.5. & 0.9 & & & \\
\hline \multirow[t]{2}{*}{1} & \multirow{2}{*}{$\begin{array}{l}\text { The social media sites help in } \\
\text { spreading the rules of prevention. }\end{array}$} & $\mathrm{F}$ & 47 & 117 & 44 & 25 & 2 & \multirow{2}{*}{157.83} & \multirow{2}{*}{3.77} & \multirow{2}{*}{ (2) } \\
\hline & & $\%$ & 20.0 & 49.8 & 18.7 & 10.6 & 0.9 & & & \\
\hline \multirow[t]{2}{*}{4} & \multirow{2}{*}{$\begin{array}{l}\text { The social media sites posts } \\
\text { information about the nutrients that } \\
\text { help protect the body from diseases }\end{array}$} & $\mathrm{F}$ & 38 & 132 & 44 & 17 & 4 & \multirow{2}{*}{214.12} & \multirow{2}{*}{3.77} & \multirow{2}{*}{ (3) } \\
\hline & & $\%$ & 16.2 & 56.2 & 18.7 & 7.2 & 1.7 & & & \\
\hline \multirow[t]{2}{*}{3} & \multirow{2}{*}{$\begin{array}{l}\text { The social media sites post } \\
\text { information about ways of infection } \\
\text { transmission }\end{array}$} & $\mathrm{F}$ & 55 & 98 & 51 & 28 & 3 & \multirow{2}{*}{105.91} & \multirow{2}{*}{3.74} & \multirow[b]{2}{*}{ (4) } \\
\hline & & $\%$ & 23.4 & 41.7 & 21.7 & 11.9 & 1.3 & & & \\
\hline \multirow[t]{2}{*}{2} & \multirow{2}{*}{$\begin{array}{l}\text { The social media sites discuss the } \\
\text { first aid procedures that can be } \\
\text { followed in case of an injury. }\end{array}$} & $\mathrm{F}$ & 62 & 81 & 64 & 22 & 6 & \multirow{2}{*}{84.59} & \multirow{2}{*}{3.72} & \multirow{2}{*}{ (5) } \\
\hline & & $\%$ & 26.4 & 34.5 & 27.2 & 9.4 & 2.6 & & & \\
\hline & Mean of Total Score of Prevention & \multicolumn{9}{|c|}{18.87} \\
\hline
\end{tabular}

$\mathrm{Chi}^{2}$ values at $(0.05) .=9.488$

Table (5) shows the statistical significance of the statements included the prevention dimension. $\mathrm{Chi}^{2}$ values ranged between 214.12 and 84.59, which are significant values at (0.05). That indicates that the students agreed that the statements included in the prevention dimension are the most important in the health education.

Table (5) shows statistically significant differences for the response (Agree) in all the 5 statements of the prevention dimension indicating that Facebook pages are concerned with giving information on symptoms of the different diseases for early treatment and avoiding complications. Khalil (2006) states that early diagnosis, in addition to the immediate treatment help decrease morbidity changes rate and take quick measures to control spread of the disease. Having protective nutrients, following safety rules and , taking quick first aid measures in case of accidents, getting rid of dead animals and insects and drinking potable water are all protective measures Khalil (2006). 
Table (6)

Responses of the sample on Facebook's effect on Health Education ( $\mathrm{N}=235$ )

\begin{tabular}{|c|c|c|c|c|c|c|c|c|c|c|}
\hline $\mathrm{N}$ & Statements & & $\begin{array}{l}\text { Strongly } \\
\text { Agree }\end{array}$ & Agree & Neutral & Disagree & $\begin{array}{l}\text { Strongly } \\
\text { disagree }\end{array}$ & $\mathrm{Chi}^{2}$ & Mean & Order \\
\hline \multirow[t]{2}{*}{1} & \multirow{2}{*}{$\begin{array}{l}\text { Facebook is the best and easiest way to get and } \\
\text { share health information. }\end{array}$} & $\mathrm{F}$ & 117 & 83 & 20 & 13 & 2 & \multirow{2}{*}{215.02} & \multirow{2}{*}{4.27} & \multirow{2}{*}{ (1) } \\
\hline & & $\%$ & 49.8 & 35.3 & 8.5 & 5.5 & 0.9 & & & \\
\hline \multirow[t]{2}{*}{13} & \multirow{2}{*}{$\begin{array}{l}\text { Facebook contributes in promoting health } \\
\text { information. }\end{array}$} & $\mathrm{F}$ & 95 & 87 & 44 & 7 & 2 & \multirow{2}{*}{160.38} & \multirow{2}{*}{4.13} & \multirow{2}{*}{ (2) } \\
\hline & & $\%$ & 40.4 & 37.0 & 18.7 & 3.0 & 0.9 & & & \\
\hline \multirow[t]{2}{*}{2} & \multirow{2}{*}{$\begin{array}{l}\text { Facebook is my primary source for the health } \\
\text { information. }\end{array}$} & $\mathrm{F}$ & 94 & 82 & 47 & 10 & 2 & \multirow{2}{*}{145.27} & \multirow{2}{*}{4.08} & \multirow{2}{*}{ (3) } \\
\hline & & $\%$ & 40.0 & 34.9 & 20.0 & 4.3 & 0.9 & & & \\
\hline \multirow[t]{2}{*}{17} & \multirow{2}{*}{$\begin{array}{l}\text { I report pages that post untrue health } \\
\text { information.to stop circulating it. }\end{array}$} & $\mathrm{F}$ & 98 & 78 & 39 & 11 & 9 & \multirow{2}{*}{135.44} & \multirow{2}{*}{4.04} & \multirow{2}{*}{ (4) } \\
\hline & & $\%$ & 41.7 & 33.2 & 16.6 & 4.7 & 3.8 & & & \\
\hline \multirow[t]{2}{*}{4} & \multirow{2}{*}{$\begin{array}{l}\text { Facebook gives room for expressing opinions and } \\
\text { exchanging views and health information. }\end{array}$} & $\mathrm{F}$ & 64 & 104 & 65 & 2 & 0 & \multirow{2}{*}{90.80} & \multirow{2}{*}{3.97} & \multirow{2}{*}{$(5)$} \\
\hline & & $\%$ & 27.2 & 44.3 & 27.7 & 0.9 & 0 & & & \\
\hline \multirow[t]{2}{*}{10} & When I read good health information on & $\mathrm{F}$ & 85 & 80 & 41 & 22 & 7 & & & \\
\hline & Facebook, I verify it through several resources. & $\%$ & 36.2 & 34.0 & 17.4 & 9.4 & 3.0 & 102.00 & 3.91 & (b) \\
\hline 12 & I actively participate in the health events and & $\mathrm{F}$ & 62 & 64 & 67 & 10 & 2 & & & \\
\hline & activities I am invited to through Facebook. & $\%$ & 26.4 & 40.0 & 28.5 & 4.3 & 0.9 & 132.51 & 3.80 & (1) \\
\hline 16 & I comment on the untrue health information so that & $\mathrm{F}$ & 70 & 91 & 49 & 17 & 8 & & & \\
\hline & it can be to be corrected. & $\%$ & 29.8 & 38.7 & 20.9 & 7.2 & 3.4 & 104.04 & 3.84 & (8) \\
\hline 7 & I make sure to cite health information given via & $\mathrm{F}$ & 65 & 86 & 65 & 19 & 0 & 108 & & (0) \\
\hline & Facebook. & $\%$ & 27.7 & 36.6 & 27.7 & 8.1 & 0 & 40.86 & 3.83 & (9) \\
\hline 8 & I read and discuss comments on the health content & $\mathrm{F}$ & 73 & 82 & 46 & 29 & 5 & 8480 & 380 & (10) \\
\hline 6 & I share and circulate the correct health information & $\mathrm{F}$ & 60 & 91 & 64 & 16 & 4 & 11072 & & \\
\hline & & $\%$ & 25.5 & 38.7 & 27.2 & 6.8 & 1.7 & 110.72 & 3.19 & (11) \\
\hline 15 & I use the Facebook to express my fear and & $\mathrm{F}$ & 74 & 80 & 47 & 17 & 17 & & & \\
\hline & $\begin{array}{l}\text { problems, exchange experiences and benefit from } \\
\text { others' experiences in the health area. }\end{array}$ & $\%$ & 31.5 & 34.0 & 20.0 & 7.2 & 7.2 & 76.97 & 3.75 & (12) \\
\hline 5 & I visit the official websites more often than the & $\mathrm{F}$ & 55 & 62 & 73 & 35 & 10 & 5272 & & (13) \\
\hline & unofficial and personal ones. & $\%$ & 23.4 & 26.4 & 31.1 & 14.9 & 4.3 & 52.72 & 3.49 & (13) \\
\hline 3 & I trust all the health information I get from the & $\mathrm{F}$ & 32 & 64 & 86 & 40 & 13 & 6803 & 326 & (14) \\
\hline & Facebook. & $\%$ & 13.6 & 27.2 & 36.6 & 17.0 & 5.5 & 68.93 & 3.26 & (14) \\
\hline 11 & Social media sites are the sole sources for the & $\mathrm{F}$ & 39 & 48 & 56 & 48 & 44 & 33 & 205 & (15) \\
\hline & health information. & $\%$ & 16.6 & 20.4 & 23.8 & 20.4 & 18.7 & 3.31 & 2.95 & (15) \\
\hline 9 & I try to apply the health information I get from the & $\mathrm{F}$ & 25 & 39 & 61 & 49 & 61 & קח & 65 & $(16)$ \\
\hline & Facebook without verifying it. & $\%$ & 10.6 & 16.6 & 26.0 & 20.9 & 26.0 & 20.08 & 2.65 & (16) \\
\hline 14 & The health information posted on Facebook can be & $\mathrm{F}$ & 14 & 17 & 50 & 106 & 48 & & & \\
\hline & $\begin{array}{l}\text { considered medical advice or a therapeutical } \\
\text { recommendation. }\end{array}$ & $\%$ & 6.0 & 7.2 & 21.3 & 45.1 & 20.4 & 116.59 & 2.33 & $(17)$ \\
\hline & $\begin{array}{c}\text { Mean of Total Score of the Facebook's effect } \\
\text { dimension }\end{array}$ & & & & & & & & 62.03 & \\
\hline
\end{tabular}

$\mathrm{Chi}^{2}$ values at $(0.05) .=9.488$

Table (6) shows the statistical significance of the $\mathrm{Chi}^{2}$ values ranged between 3.31 and 215.02, which are statements included in the Facebook's effect dimension.

significant values at $(0.05)$ expect for item 11 which reads 
"Social media sites are the only sources for the health information". That indicates that the students agreed that most statements included in that dimension are the most important in spreading the health education.

Table (6) also shows statistically significant differences for the response (Strongly Agree) in 5 statements of the dimension; 1.2.10.13.17. There are also statistically significant differences for the response (Agree) in 6 statements; 4.6.7.8.15.16. Additionally, there are statistically significant differences for the response (Neutral) in 4 statements; 3.5.11.12. There are also statistically significant differences for the response (Disagree) in one item; item 14 . There are also statistically significant differences for the response (Strongly Disagree) in item 9 only.

The researcher believes these responses are logical considering Facebook's popularity, the large number of users, especially young people and the easiness of exchanging information and sharing it and commenting on it, as stated by item 1 and item 2 as well which refers to the Facebook as a primary source for health information. This reflects the increased awareness of both male and female students of the importance of verifying the source of the given information and citing it. This concurs with the result of item 10 which refers to the necessity of verifying the given health information in several resources, the result of item 6 which refers to commenting on the untrue health information so it can be corrected and the result of item 17 which refers to reporting pages that publish untrue health information.
This is consistent with the fact that social media are the main way of spreading information and consolidating the components of civilization especially when the content is put in a way that corresponds to the demands, aspirations, aims and values of the society. Mass media in modern times can also be very beneficial in teaching, self-learning and adult education.

"A Look at the Social Media in the Arab World" report states that $23 \%$ of Egyptians (16600000) use Facebook. Facebook has also a great effect on the public opinion formation, developing the moral, social national and religious values, increase of the knowledge of the public and their ability to accept change Mohamed Bin Rashid School of government (2014), Al Abdallah (2005).

Mass Media aim to increase the awareness of the citizens from all ages and educational levels of the different problems helping society to assume an effective role in dealing with the current and the key health issues Alsharq Issue (2012).

When we talk about the internet and the communication revolution and the society utilizing it, we talk about epapers, blogs, Facebook pages, Twitter, Youtube, etc.... as they are successful and capable of expressing the needs and the aspirations of the young people. They have contributed recently in bringing the attention to a lot of the issues that mattered to the public opinion Bin Gably (2007).

Table (7)

Significance of the differences between male and Female Students in Dimension of Health Education and social networks (N1+N2=235)

\begin{tabular}{|c|c|c|c|c|c|}
\hline \multirow{2}{*}{ Dimension } & \multicolumn{2}{|c|}{ MALE } & \multicolumn{2}{|c|}{ FEMALE } & Std.Deviation \\
\cline { 2 - 6 } & Mean & Std.Deviation & Mean & 2.16 & 1.356 \\
\hline the personal hygiene & 15.45 & 2.78 & 15.01 & 3.59 & $3.187 *$ \\
\hline the nutrition & 27.78 & 3.93 & 26.22 & 3.04 & $2.984^{*}$ \\
\hline the environmental health & 14.75 & 3.65 & 13.45 & 10.54 & 2.18 \\
\hline the posture health & 11.38 & 2.02 & 18.26 & 3.34 & $2.953^{*}$ \\
\hline the Prevention & 19.58 & 3.47 & 83.50 & 10.56 & $3.854^{*}$ \\
\hline the total score of health education & 88.97 & 11.15 & 61.92 & 6.39 & 0.305 \\
\hline
\end{tabular}

$\mathrm{T}$ values at $(0.05) .=1.96$

Table (7) shows statistically significant differences between male and female students in some dimensions of the health education (nutrition - environmental health postural health -disease prevention-the total score of health education) in favour of the males. That means that male students have better health education than female students. There are no differences in the personal hygiene dimension nor the effect of Facebook between the two genders. 
Table (8)

Significance of the differences between urban and rural Students

in Dimension of Health Education and social networks (N1=235)

\begin{tabular}{|c|c|c|c|c|c|}
\hline \multirow{2}{*}{ Dimension } & \multicolumn{2}{|c|}{ urban } & \multicolumn{2}{c|}{ Rural } \\
\cline { 2 - 6 } & Mean & Std.Deviation & Mean & Std.Deviation \\
\hline the personal hygiene & 15.36 & 2.38 & 14.93 & 2.61 & 1.264 \\
\hline the nutrition & 27.36 & 3.58 & 26.14 & 4.14 & $3.350^{*}$ \\
\hline the environmental health & 13.84 & 3.53 & 14.43 & 1.272 \\
\hline the posture health & 10.98 & 2.24 & 10.84 & 1.97 & 0.471 \\
\hline the Prevention & 19.02 & 3.42 & 18.58 & 3.53 & 0.931 \\
\hline the total score of health education & 86.58 & 10.60 & 84.95 & 12.10 & 1.072 \\
\hline social networks & 61.43 & 6.26 & 63.15 & 5.77 & $2.069 *$ \\
\hline
\end{tabular}

$\mathrm{T}$ values at $(0.05) .=1.96$

Table (8) shows statistically significant differences between rural and urban students in some of the health education dimensions; nutrition, for the urban Students. However, there are differences between the two groups in these dimensions: personal hygiene, environmental health, posture health. There are also statistically significant differences between rural and urban students in
Facebook's effect for the rural students. This indicates indicating a close health education level of two groups (rural \& urban). This is due to the popularity of the different mass media and social media, like Facebook, in particular which helped in spreading a lot of health education.

Table (9)

Significance of the differences between humanities and science majors Students in Dimension of Health Education and social networks $(\mathrm{N} 1+\mathrm{N} 2=235)$

\begin{tabular}{|c|c|c|c|c|c|}
\hline \multirow{2}{*}{ Dimension } & \multicolumn{2}{|c|}{ science } & \multicolumn{2}{|c|}{ humanities } \\
\cline { 2 - 5 } & Mean & Std.Deviation & Mean & Std.Deviation \\
\hline the personal hygiene & 15.25 & 2.25 & 15.19 & 2.59 & 0.195 \\
\hline the nutrition & 25.82 & 3.72 & 27.57 & 3.75 & $3.444^{*}$ \\
\hline the environmental health & 13.00 & 3.16 & 14.65 & 3.37 & $3.687^{*}$ \\
\hline the posture health & 10.11 & 1.71 & 11.39 & 2.24 & $4.543^{*}$ \\
\hline the Prevention & 17.40 & 2.74 & 19.70 & 3.54 & $5.175^{*}$ \\
\hline the total score of health education & 81.60 & 10.17 & 88.52 & 10.93 & $4.777^{*}$ \\
\hline social networks & 59.52 & 5.48 & 63.45 & 6.05 & $4.934^{*}$ \\
\hline
\end{tabular}

$\mathrm{T}$ values at $(0.05) .=1.96$

Table (9) shows statistically significant differences between the science and the humanities majors in some dimensions of health education (nutrition - environmental health - postural health - disease prevention-the total score of health education) for the humanities major students. However, there are no differences in the personal hygiene dimension. There are also statistically significant differences between the two groups in the effect of Facebook for the humanities major students. These results may be due to the nature of the science study; science study does not allow a lot leisure time to pass on Facebook.

\section{Conclusions}

Zagazig University students have high health education level.

Facebook affects the health education level of the students.

There are no differences between in health education level of the students based on gender.

There are no differences between in health education level of the students based on place of living (urban \& rural). 
There are differences between in health education level of the students based on major in favour of humanities students.

\section{Recommendation}

Further research should be done on social media's effect on different groups of the society.

Utilizing Facebook in spreading the correct health education.

Facebook users who publish untrue life- threating health information should be punished.

Awareness raising workshops should be held to teach all the members of the society how to deal with information of the social networks and verifying it.

Health institutions should start Facebbok pages to face the irresponsible pages that post untrue health information to the young people.

\section{References}

1- Abd Al Wahaab, Farouq (1995) : Sport Health and Fitness, Cairo, Dar Al Shouroq, 160.

2- Ahmed. Al Shaimaa Abel Monaim, (2009): Sports Mass Media and its role in Spreading the Health Education among Athletes. Master Thesis, College of Physical Education, Minia University,Egypt.

3- Al Abdallah, Mai (2005): Communication and Democracy, Beirut, Dar Al Nahda Al Arabia, 21. Alsharq Issue (Issue 299). Health MediaThe new awareness weapon $\quad$,page $20 \quad 28 / 9 / 2012$. http://www.alsharq.net.sa/2012/09/28/508776

4- Al Deleemy, Abdel Raziq \& Al Maiata, Mosab (2014) : The Role of TV in Health Awareness, Paper presented at First Conference of Health Mass Media, Amman, Jordan.

5- Al Mansour, Mohamed (2012) The effect of Social Networks on the Audience -Comparative Study for Social Media and the Electronic Sites: Unpublished Master Thesis, The Open Arab Academy, Denmark, 76-78.

6- Al Shehry, Hanan Shaishoo (2013): The effect of Social networks on the Social Relationships :Twitter \& Facebook, Master Thesis, College of Arts and Science, King Abdul Aziz, Saudi Arabia.

7- Bin Gably, Saeed(2007, December): Watching The New Media and its relationship to the Public Opinion -the
Weapon of the Marginalized Arabs, Paper presented at Cairo Festival for Mass Media, Cairo. Egypt.

8- Hagar, Suliman Ali \& Al Amin, Mohamed Al Sayed (1998): General Rules of Health \& Health Education, Cairo, Al Ghad, 126.

9- Ismail, Kamal Abdel Hamid \& Abdel Fattah, Abu Al Aila Ahmed (2001): Health Education for Athletes, Cairo, Dar Al Fekr Al Arab, 251.

10- Karbiniski, Aren.(2010) Facebook and the technology revolution, N,Y Spectrum Puplications

11- Khadr, Nermin (2009, February). The Social and Psychological Effects of the Use of Egyptian Youth's Use of Social Networks, Paper presented at First Conference for Family, Mass Media \& the New Era's Challenges, , Faculty of Mass Communication, Cairo University, Egypt

12- Khalil, Sameia (2006) :Health Education For Athletes, Iraq, Baghdad Publishing House, 21-50.

13- Mohamed Bin Rashid School of government (2014): A Look at the Social Media in the Arab World Report, from: http://www.mbrsg.ae/getattachment/9cea0fcc-9e434fba-9f47-ea6d9d16ca8c/Arab-Social-Media-Outlook2014.aspx

14- Mohamed, Mona Hussein (2013):The role of the Internet in forming the Social Values of the University Students, M.A. Thesis, Monofia University, Egypt.

15- Qassem, Medhat (2005): The Healthy Life, Cairo. Alam Al Kotb, 159-161.

16- Salma, Bahaa Al Din Ibrahim (2012): Personal Hygiene and Health Education, Cairo, Dar Al Fekr Al Araby , 24- 28.

17- Streck, Helen: (2011) Social Networks And Their Impact On Records Information Management, Aram International Educational Foundation

18- Vansoon, Mecheel.(2010) Facebook and the invasion of technological communities , N.Y,Newyurk.

19- http://vb.elmstba.com/t247664.html

20-

http://arabic.cnn.com/2011/scitech/9/18/internet.arab/inde x.html 